\title{
Seasonality, abundance, species richness and specificity of the phytophagous guild of insects on oak (Quercus) canopies
}

\author{
T. Richard E. SOUTHWOOD, G.R. William WINT, CAtherine E.J. KENNEDY* and Steve R. GREENWOOD** \\ Department of Zoology, South Parks Road, Oxford OX1 3PS, U.K.; e-mail: richard.southwood@zoology.oxford.ac.uk
}

Key words. Phytophagous guild, Quercus, biomass, species richness, introduced species

\begin{abstract}
A study was made by knockdown sampling and branch clipping of the arthropod fauna of two native oaks (Quercus petraea and $Q$. robur) and of two introduced species (Q. cerris and $Q$. ilex) in woods near Oxford, U.K., and of two native species (Q. ilex and Q. pubescens) in southern France. Sampling was undertaken for five years in England and four years in France. All the phytophagous species except Acarina and Cecidomyidae from the Oxford samples were identified to species.

2. In England a marked seasonal pattern was observed in all years: chewing insects peaked in May, followed sequentially by sucking species, leaf miners and gall formers. The May peak on the native trees is much larger in terms of individuals, and especially in biomass, than on the introduced species. This peak is well known to provide an important food source for several species of woodland bird.

3. Most phytophages were much less abundant on the introduced oaks than on the native species. This is probably due more to the features of the leaves, than to the introduced status per se.

4. The species richness of the fauna was estimated by three methods on the basis of the total projected number of species $\left(\mathrm{S}_{\max }\right)$, and its specificity to oak by reference to the known host range as recorded in the standard reference works.

5. The species richness of Heteroptera and Coleoptera on the deciduous oaks in their natural habitats $(Q$. petraea and $Q$. robur in England, Q. pubescens in France) are similar.

6. The fauna of the evergreen $Q$. ilex has a similar species richness both in France, where it is native, and in England, where it is introduced and where its phytophage guild is smaller than that of the deciduous species. In England the extent of oak specificity on Q. ilex is less than that of the deciduous species.

7. In England the phytophage fauna of the deciduous and introduced $Q$. cerris has a species richness considerably greater than that found on $Q$. ilex, but somewhat less than that of the deciduous and native oaks. However, the specificity of this fauna to oaks was not significantly different to that of the fauna on the native oaks.
\end{abstract}

\section{INTRODUCTION}

In the last two decades there have been many studies of the communities of arthropods on trees, which have the advantage to the ecologist of being discrete habitats whose total invertebrate fauna can be sampled (Stork et al., 1997; Linsenmair et al., 2001; Basset et al., 2003). Most frequently used is a technique involving knockdown, with a quick acting insecticide, and the fauna is collected as it falls from the tree. This technique was first used by Collyer (1951), who collected the total fauna of the tree; subsequently most workers have taken samples using only a limited number of sheets or funnels, an approach first followed by Martin (1966).

Many of the existing studies have been based on a single sampling occasion (e.g. Moran \& Southwood, 1982; Kitching et al., 1993; Ozanne et al., 2000), or throughout a single season (e.g. Stork \& Brendell, 1990; Recher et al., 1996), although some studies have been extended for a longer period (e.g. Basset \& Arthington, 1992). One purpose of the present study, only part of which is reported here, was to determine the seasonal pattern and guild structure based on several seasons and to assess whether the generalisations made for these shorter sampling seasons would hold over a longer time-frame.

The other aim was to assess quantitatively and qualitatively the development of the arthropod canopy community on closely related introduced and native trees. Studies in tropical forests have shown that most herbivorous insects feed on several closely related plant species (Basset et al., 1997; Novotny et al., 2002). There is some evidence that introduced species are colonised by phytophages with host plant ranges which are on average broader than those on long established native species (Southwood \& Kennedy, 1983), while the overall abundance and diversity are less (Southwood et al., 1982a). It was considered that the communities on the members of the genus Quercus would provide a good system with which to explore these ideas further. The species native to Britain ( $Q$. robur, $Q$. petraea) have the largest number of associated insects of any tree in Britain (Kennedy \& Southwood, 1984), thereby providing a large species pool. There are two introduced species of oak $(Q$. cerris, $Q$. ilex) which in some places, including the chosen sample sites at Oxford, grow alongside the native species. The natural ranges of both introduced species are Medi-

\footnotetext{
* now at Oxford University Press, Great Clarendon Street, Oxford OX2 6DP, U.K.

** now at BBC Natural History Unit, Whiteladies Road, Bristol, BS8 2LR, U.K.
} 
terranean and Near-Eastern. One of the species (Q. ilex) is evergreen. A parallel study in the south of France of the arthropod community on this evergreen oak and on the deciduous oak ( $Q$. pubescens), dominant there, allows the analysis of the influence of evergreenness and of the introduced status in Britain. Because the entomofauna of Western Europe is well known, virtually all the phytophages and many of the other insects could be identified to species so that the existing bank of knowledge could be utilised in the analysis.

\section{METHODS}

\section{Sites}

In the U.K., four species of oak, two native (Quercus robur and $Q$. petraea $)$ and two introduced $(Q$. cerris and $Q$. ilex) were studied near Oxford: Q. robur, Q. cerris, and Q. ilex in Wytham Wood $\left(57^{\circ} 46^{\prime} \mathrm{N}, 1^{\circ} 19^{\prime} \mathrm{W}\right)$ and $Q$. robur and $Q$. petraea in Bagley Wood $\left(57^{\circ} 43^{\prime} \mathrm{N}, 1^{\circ} 15^{\prime} \mathrm{W}\right)$. Work was also undertaken in the Cevennes, France, in the hamlet of L'Elzière, Mars, Gard $\left(44^{\circ} 0^{\prime \prime} \mathrm{n}, 3^{\circ} 33^{\prime} \mathrm{R}\right)$, where $Q$. ilex and a deciduous species, $Q$. pubescens are native to the area and form rather scrubby woodlands.

\section{Sampling}

The entomofauna was "knocked down" from the trees by mistblowing as used by Southwood et al., (1982b). The method is described by several other authors, most recently Kitching et al., (2002). The trees were sprayed with Neopybuthrin at a concentration of $50 \mathrm{cc}$ per litre of water. Each tree had the relevant portion of its foliage sprayed for 2-3 minutes from a variety of ground positions; the sprayer was then hoisted into the canopy to ensure good coverage of the foliage up to $10 \mathrm{~m}$ (as seen by leaf movement when spraying). Samples of the insects and spiders that fell from the tree were collected on the $1 \mathrm{~m}^{2}$ sheets held on a frame with legs adjusted to be of sufficient length to lift them above any ground vegetation. The trays were placed in a straight line from the bole of the tree to the outer edge of the canopy. One person collected continuously for one hour from the sheets under each tree, after which the sheets were left in position and revisited until there was no further catch. The drop down time for mistblowing sampling is probably less than that for fogging (Stork \& Hammond, 1997); this is likely to be due to the larger size and greater velocity of the insecticide droplets produced in misting. The specimens were immediately preserved in $70 \%$ alcohol with $5 \%$ by volume, of glycerine; subsequently they were separated into orders or suborders and the total number recorded. These ordinal sub-samples were then identified to species in all groups except the Diptera Nematocera, Acari and Collembola. Some Hymenoptera Parasitica and Staphylinoidea could only be taken to morphospecies. The lengths were determined and biomass calculated from the formula of Rogers et al., (1976):

\section{$\mathrm{B}=0.0305\left((\text { length })^{2.62}\right)$}

Altogether some 61,000 specimens (of all guilds) were identified from the material collected in Britain. The full data set, with the names of those responsible for the identifications, will be deposited in the University Museum of Natural History, Oxford, and made available on a CD.

Of the French material, only the Psocoptera (epiphyte guild) and the Heteroptera and Coleoptera (except Staphylinoidea) have so far been identified to species. These accounted for approximately $11 \%$ of an ordinal count of 11,753 .

The fieldwork was carried out in 1980-84. During the first year in Oxford seven collecting trays were placed under each tree, but thereafter the number was reduced to four per tree. The catches from the four $1 \mathrm{~m}^{2}$ trays under one tree are taken to represent "tree-sample" and therefore for analyses the 1980 total numbers were reduced to $4 / 7$ ths, and $40 \%$ of the resulting singletons removed. The trees in France being smaller, only two trays were used per tree and, as the trees were shorter, the volume of foliage sampled by each sheet was less. Comparisons of abundance per 'tree-sample' for the trees in France with those in the UK are thus not possible, though comparisons can be made in terms of species richness expressed as $\mathrm{S}_{\max }$.

In Oxford sampling was carried out in April (just before budburst) and every month until and including October - 183 sampling days in all. In France over 1981-84 there were 42 sampling days in the months May to August.

Branch samples were also taken at all sites at the time of spraying enabling a count to be made of leaf mines and galls; virtually no sessile insects were found on these samples. Leaf damage was also assessed on these samples. Branch sampling has been shown to be complementary to knockdown (Majer \& Recher, 1988).

\section{Analysis}

The knockdown data were originally entered into a series of INGRES relational databases, for Insect Characteristics (keyID, taxonomy, guild, length, biomass); Insect Number (KeyID, SampleID, Number Adults, Number Young); and Tree Name (SampleID, Date, TreeID, Tree Species, Site, Herbivory level, Volume misted, Number leaves misted, leaf length). This format minimised duplicate entries, for example of insect names, and so facilitated error checking and validation. The cleaned data were then amalgamated into a flat rectangular database in Statistical Package for the Social Sciences (SPSS) format, with each row representing a species abundance record for a particular sample occasion. Statistical descriptions and groups analyses were performed using the SPSS ANOVA module for one-way Analysis of Variance and the General Linear Model (GLM) UNIANOVA module for univariate Analysis of Variance if a number of fixed factors were being assessed. The default (type III) for sums of squares were used throughout.

As the numbers of individuals sampled varied so greatly between the tree species, the most useful comparator for species richness is an estimate of $S_{\max }$ : the total number of species of insect that would be found in the habitat if sampling was continued until no new species were found. (In practice the occasional new species will continue to be found, a vagrant from the species pool of the geographical area rather than a member of the community). We use three estimators: Michaelis-Menton, Chao quantitative and the First Order Jackknife, which have different assumptions (Colwell \& Coddington, 1994; Southwood \& Henderson, 2000).

Specificity to oak was assessed by ranking all the phytophages found in the sites near Oxford on a scale of 1-12. Those restricted to Quercus were given a rank of 12 whilst those with increasing breadth of diet or lack of normal association with oaks, were ranked accordingly down to 1 (Appendix 2). These rankings were based on the description of the species' habitat as given in the standard works of reference. An analysis was conducted in two ways. Firstly, weighting was by abundance so each occurrence of a species was given the appropriate "oak code" and the overall average was calculated. In the second method the rankings for each species found were simply aggregated, thus only a single entry for each species was used for the calculation of the "average oak code". 

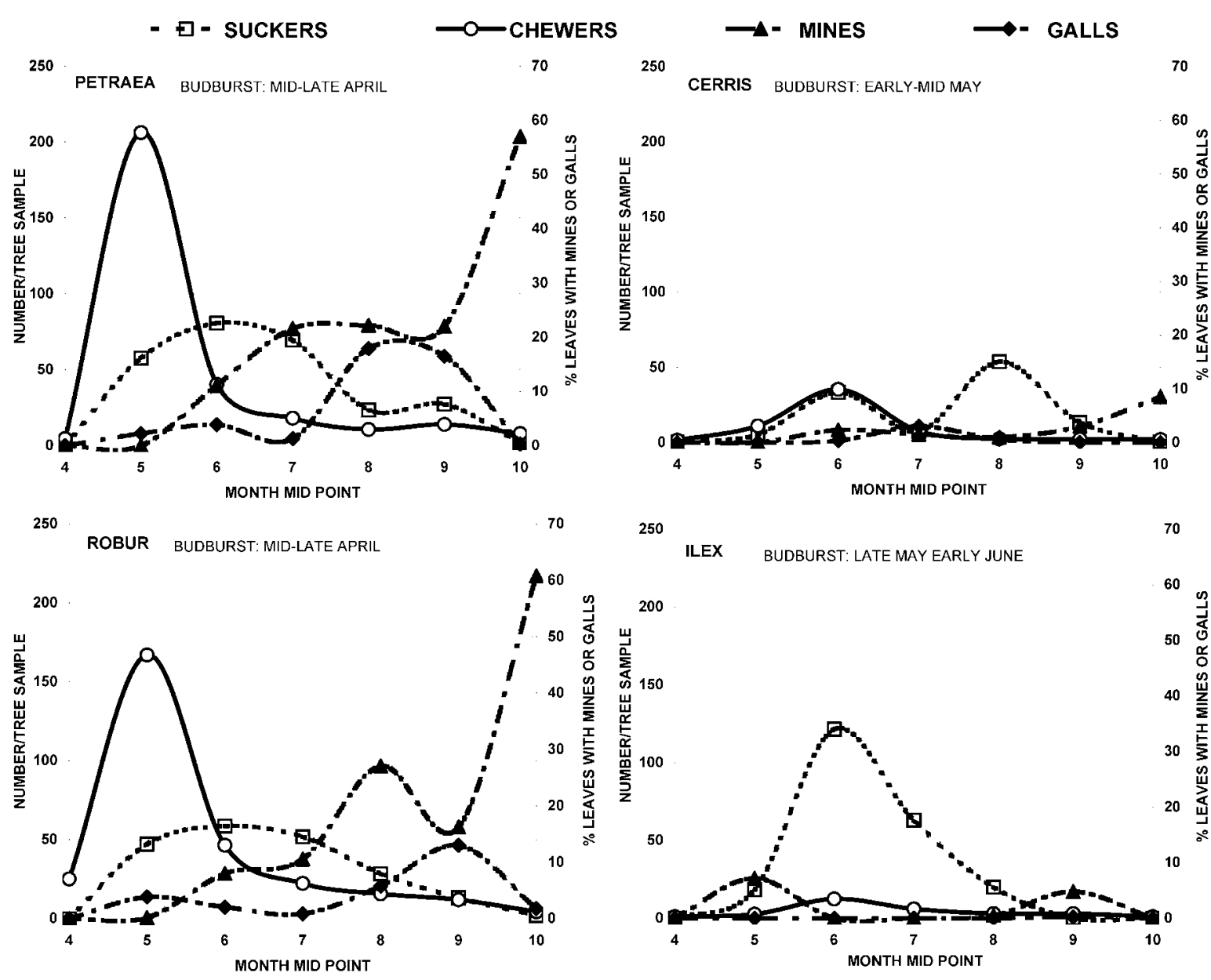

Fig. 1. The seasonal trends in phytophages (chewers, suckers, leaf miners, galls) in terms of abundance on four species of oak near Oxford (note differences in scales). Data in Appendix 1.

\section{RESULTS}

The seasonal pattern of phytophage abundance in the U.K.

On the deciduous oaks, the total number of phytophagous insects in the knockdown samples rises in early May (following budburst), peaking in that month and again, but to a much lower level, in July and August. The regularity of the annual pattern is shown by the nonsignificance of any difference in the seasonal trends during the years 1980 to 1984 inclusive on Q. robur at Wytham (Table 1).

In terms of biomass, the spring peak on the native species in the U.K. consists mainly of chewers, mostly lepidopterous larvae. On average these form a remarkably similar proportion of the canopy fauna on $Q$. robur and Q. petraea (Table 2), though the level of abundance varies from year to year.

TABLE 1. Statistics for interannual variation of monthly biomass/tree sample, for $Q$. robur in Wytham.

\begin{tabular}{lccc}
\hline Guild & DF & F & P \\
\hline Chewers & 4.35 & 2.27 & 0.096, NS \\
Suckers & 4.35 & 1.32 & 0.297, NS \\
Mines & 4.41 & 1.60 & 0.215, NS \\
Galls & 4.38 & 0.81 & 0.535, NS \\
\hline
\end{tabular}

The average seasonal trends in terms of the numbers of phytophages on all four species of oak are shown in Fig. 1 ; the patterns are very similar in the two native species, with leaf mines and galls peaking in late summer and early autumn; the leaf mines rise to a high accumulated total during leaf-fall, because mined leaves generally remain on the tree longer than other leaves. The autumnal peak of galls was mostly due to the agamic generation of Neuroterus spp.

On $Q$. cerris, the same basic patterns for chewers and leaf mines were found, but galls peaked earlier and sucking phytophages were relatively more numerous with a peak (of aphids) in August. Q. ilex has a unique pattern: leaf mines peak in the spring before the oldest leaves, with deserted mines, have fallen; sucking species peak in June, soon after the new leaves emerge; chewing species are relatively rare, and galls more so.

TABle 2. The proportion that Lepidoptera contribute to the annual and the May biomass of phytophages and total canopy fauna.

\begin{tabular}{lcclccc}
\hline & \multicolumn{2}{c}{$\%$ Annual total } & & \multicolumn{2}{c}{$\%$ May total } \\
\cline { 2 - 3 } \cline { 5 - 6 } & phytophages & fauna & & phytophages & fauna \\
\hline Q. robur & 66.7 & 46.9 & & 93.0 & 88.0 \\
Q. petraea & 66.3 & 45.7 & & 94.0 & 87.8 \\
\hline
\end{tabular}




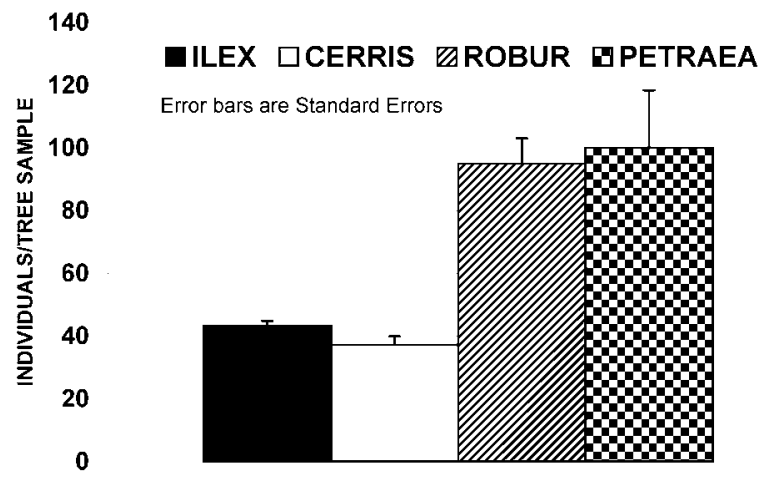

Fig. 2. The average total individual phytophages per season on the four species of oak in the U.K.

\section{The size of the phytophage community on the different species of oak in the U.K.}

In terms of individuals per tree-sample, the two native oaks ( $Q$. robur and $Q$. petraea) have very similar and much larger populations than those found on the introduced species ( $p<0.0004$ ) (Fig. 2, see also Fig. 1). Expressed as biomass, this contrast between the native and introduced oaks is even more marked and can be attributed almost entirely to the large number of phytophages, predominantly chewers (Fig. 1), at their peak in May (Fig. 3). It can be seen from Fig. 3 that the late summer peak of sucking phytophages on $Q$. cerris does not translate into a significant biomass available to predators. The numbers of leaf mines and galls were far lower on the introduced trees (Table 3).

It is also worth noting that the mean abundance per tree sample of phytophages on Q. robur in Bagley (mean 89.3, sd 95.19) and that in Wytham Wood (mean 100.6, sd 87.66) were similar $(\mathrm{F}=0.317, \mathrm{DF} 1.83, \mathrm{p}=0.575)$, showing that in this large and long data set local effects on abundance are minimal.

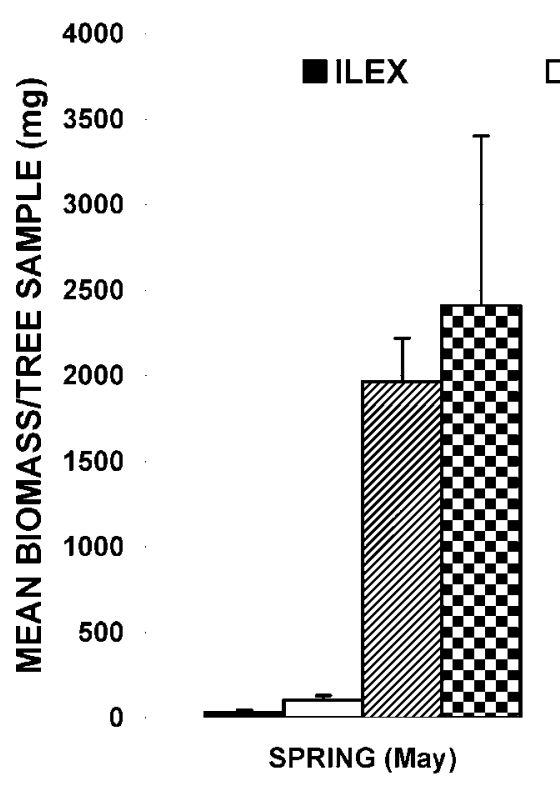

TABLE 3. The numbers of leaf mines and galls per 100 leaves on the four species of Quercus at Oxford.

\begin{tabular}{lcccc}
\hline & cerris & ilex & petraea & robur \\
\hline Mines & $8.5 \mathrm{sd}=5.0$ & $7.2 \mathrm{sd}=16.1$ & $57.00 \mathrm{sd}=17.4$ & $60.8 \mathrm{sd}=14.5$ \\
Galls & $3.0 \mathrm{sd}=1.4$ & $0.20 \mathrm{sd}=0.5$ & $17.91 \mathrm{sd}=18.3$ & $13.00 \mathrm{sd}=11.2$ \\
\hline
\end{tabular}

\section{Species richness}

In the U.K. the estimates of species richness, expressed as $S_{\max }$ (using three different methods) are similar for the two native oaks, although $Q$. robur is always shown to have a slightly richer phytophage fauna than $Q$. petraea (Table 4). The phytophage fauna of these native oaks are about twice as species rich as those of the introduced and evergreen $Q$. ilex, while for $Q$. cerris the score is intermediate. Unfortunately, in the samples from France, only the Heteroptera and Coleoptera (excluding Staphylinoidea) of the non-epiphyte guilds were identified to species, but the $S_{\max }$ for these samples can be compared with the equivalent samples from the oaks at Oxford (Table 4). If $Q$. pubescens is taken as showing the species pool on the dominant native deciduous oak in that region of southern France, it would appear that the species richness is, if anything, somewhat greater than that on the most abundant British oak, $Q$. robur. But the species richness on $Q$. ilex in southern France, where it is native and abundant, is less than that of the deciduous species ( $Q$. pubescens) and apparently very similar to that found in the UK. The depauperate fauna on Q. ilex in Britain would seem to be a feature of the tree, probably relating to its evergreenness and different seasonality, rather than being dependent on its introduced status. Confirmation of whether, as seems likely, deciduous species introduced to new habitats have arthropod communities of slightly lower richness (and much lower population size), as seen in Q. cerris in the U.K., will depend on future studies of that species in its native habitat, or on Q. pubescens in the U.K. However, one would expect a "rarer" tree to have a smaller fauna (Kennedy \& Southwood, 1984).

QROBUR GPETRAEA

Error Bars are Standard Errors

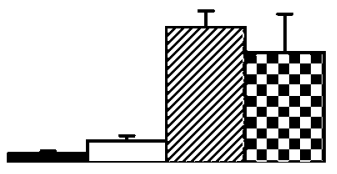

Annual Mean

Fig. 3. The biomass of phytophages in spring and in late summer, and the mean for the year, on the four species of oak. 
TABLE 4. Estimates of the total number of phytophage species $\left(S_{\max }\right)$ for different communities on the various species of oak.

\begin{tabular}{|c|c|c|c|c|c|c|c|c|c|c|c|}
\hline & \multirow[b]{2}{*}{ Tree } & \multicolumn{4}{|c|}{$\begin{array}{l}\text { All orders } \\
\text { Whole year }\end{array}$} & \multicolumn{6}{|c|}{$\begin{array}{c}\text { Heteroptera and Coleoptera } \\
\text { May to August }\end{array}$} \\
\hline & & petraea & robur & cerris & ilex & ilex & ilex & pubescens & robur & cerris & petraea \\
\hline & Country & UK & UK & UK & UK & UK & FR & FR & $\begin{array}{l}\text { Bagley } \\
\text { UK }\end{array}$ & UK & $\mathbf{U K}$ \\
\hline & Observed spp & 204 & 285 & 144 & 84 & 21 & 29 & 39 & 48 & 37 & 41 \\
\hline \multicolumn{12}{|c|}{ Smax method } \\
\hline \multicolumn{12}{|l|}{ Michealis- } \\
\hline Menton & Value & 261.3 & 319.9 & 218.5 & 174.5 & 35.8 & 30.1 & 67.5 & 58.5 & 47.0 & 48.5 \\
\hline Chao & Value & 303.0 & 355.1 & 208.7 & 121.6 & 31.5 & 31.7 & 84.3 & 57.9 & 44.3 & 47.8 \\
\hline Quantitative & SD & 26.0 & 17.6 & 18.4 & 13.9 & 7.5 & 7.7 & 23.8 & 6.4 & 5.4 & 4.8 \\
\hline 1 st order & Value & 277.2 & 370.1 & 208.2 & 134.8 & 31.3 & 31.3 & 57.7 & 62.2 & 48.5 & 52.4 \\
\hline \multirow[t]{2}{*}{ Jackknife } & SD & 10.9 & 10.2 & 12.0 & 10.6 & 3.2 & 3.1 & 4.4 & 4.2 & 4.1 & 3.4 \\
\hline & $\mathbf{N}$ & 42 & 84 & 35 & 22 & 19 & 15 & 19 & 48 & 27 & 33 \\
\hline
\end{tabular}

\section{Specificity to oak}

The two methods for calculating this characteristic give broadly similar results (Table 5), but the weighted code is the better reflection of the community. The three deciduous species in the U.K. have significantly higher 'average oak code' values than the evergreen $Q$. ilex (weighted method $\mathrm{F}=135.8, \mathrm{df}=1,2569, \mathrm{p}=<0.0001$; aggregated method $\mathrm{F}=27.09$, df $=1,547, \mathrm{p}<0.0001)$. However, for the deciduous species, where the values are broadly similar, the influence of the tree's abundance is shown in the relative values of these codings. Those phytophage species more specialised on oak make up a larger proportion of the community on the two native species (ie the weighted average code is higher for the native oaks). The larger sample of insects from $Q$. robur lowers the aggregated oak code because, as species accumulate, an increasing number of insects are found which have a low association with oaks. Such species may in reality be tourists (sensu Moran \& Southwood, 1982) but, as phytophages, they do have the potential to adapt to oak (Southwood \& Kennedy, 1983).

\section{DISCUSSION AND CONCLUSIONS}

In Britain the phytophage community of native deciduous oaks exhibits a regular seasonal pattern with chewing species peaking first, followed sequentially by peaks of sucking species, leaf miners and gall formers. These seasonal patterns can be related to the condition of the leaves. The young leaves are tender and relatively nutritious but, as the leaves age, they become tougher and less nutritious (Feeny, 1970; Wint, 1983). These older leaves are barriers to chewing insects, but not to sucking

TABLE 5 . The extent of specificity shown by the "average oak codes" as calculated by the two methods.

\begin{tabular}{lccc}
\hline & Weighted oak code & Aggregated oak code & $\mathrm{N}$ \\
\hline petraea & $9.5, \mathrm{sd} 2.8$ & $8.5, \mathrm{sd} 3.8$ & 157 \\
robur & $9.4, \mathrm{sd} 3.8$ & $7.9, \mathrm{sd} 3.8$ & 214 \\
cerris & $8.4, \mathrm{sd} 3.5$ & $8.3, \mathrm{sd} 3.5$ & 105 \\
ilex & $5.9, \mathrm{sd} 4.0$ & $5.7, \mathrm{sd} 3.8$ & 214 \\
\hline
\end{tabular}

insects, whose stylets pass directly into the phloem or xylem. Furthermore aphids, which are numerically the most abundant, are multivoltine so their populations can continue to build up over the summer. It seems that survival of leaf miners is likely to be greater if they avoid the period of maximum defoliation and leaf expansion and this is the acceptable evolutionary explanation of their seasonality (West, 1983), though early defoliation impacts adversely on those phytophages feeding later in the season (Hunter \& West, 1990).

In terms of biomass, the chewing species account for a marked peak in May (Fig. 3). The magnitude of this peak varies from year to year, but the basic regularity contrasts with the situation on eucalyptus in Australia where the variations between years can be as great as that between seasons (Recher et al., 1996). This peak of insects is a very important food source for birds, especially tits (Parus spp.). They are fed to the nestlings, and tit breeding is closely correlated with the magnitude and timing of the flush of insects (Perrins, 1991; Buse et al., 1999). The introduced (exotic) oaks studied here do not exhibit this peak and thus plantations of such oaks will not support a large population of insectivorous birds. However, sampling from the introduced Quercus borealis, Welch (1981) found more lepidopterous larvae, though fewer members of the other orders than on $Q$. robur. The length of time a tree has been present in an area can also affect the species richness of its community (Southwood \& Kennedy, 1983), but in this case this effect is completely outweighed by other factors, for the dates are: Q. ilex 1580, Q. cerris 1735 and Q. borealis 1800. It may be suggested therefore that the extent of the colonisation of an introduced tree, in terms of insect abundance will depend not simply on those features reflected in its taxonomic relatedness or on time since introduction, but also on detailed features such as those of the leaf surface. $Q$. cerris and $Q$. ilex have a dense covering of trichomes on the underside of the leaf, whilst $Q$. robur and $Q$. petraea are glabrous (Kennedy, 1986; unpublished), as is $Q$. borealis. 
The most distinct leaf structure is found in the evergreen $Q$. ilex which has a very different faunal profile to that of the deciduous species: the overall species richness, as determined by a calculated $\mathrm{S}_{\max }$, and the specificity as shown by the average oak codes, is similar. The species richness in England, where it is introduced, is comparable to that found in southern France, its native habitat (Table 4). That these long-lived evergreen leaves are more resistant to herbivory accords with general theory (Coley et al., 1985; Southwood et al., 1986).

The situation with $Q$. cerris is different for, though it shares with $Q$. ilex the feature of a low population of phytophages, its species richness (measured by $\mathrm{S}_{\max }$ ) approaches that of the native English oaks, while the specificity as shown by the average oak codes is similar. Thus it appears that a large part of the species pool of oak insects are present on $Q$. cerris, at least when growing in close proximity to other oaks, but that these phytophages are not as abundant as on native oaks. Leaf miners and gall makers, which are more intimately associated with the leaf, are scarce (Table 3).

It is noteworthy that in its natural habitat (France) $Q$. pubescens which, as its name implies, has many trichomes (especially on the petiole), had the same, or slightly higher, species richness in Heteroptera and Coleoptera than the glabrous $Q$. robur and $Q$. petraea in their natural habitat (U.K.).

ACKNOWLEDGEMENTS. Our thanks are due to: Dr. J. Kathrithamby for the identifications of the Homoptera Auchenorrhyncha; Mr C A O'Toole for the Cynipidae and Symphyta; Dr. G.C. McGavin for some of the Heteroptera; L. Atkinson, J. Killick and A. Whittaker, who at various stages assisted with the compilation of the data; and former students who helped with the fieldwork and ordinal sorting. We are grateful to the President and Fellows of St John's College, Oxford, for permission to work in Bagley Wood, and to M. Ferdinand Galtier, the then Mayor of Mars, Gard, France, for his permission to work on the community's land and his own property. Dr. Peter Henderson (Pisces Ltd) kindly made available to us his programme for the calculation of $S_{\max }$. We are indebted to the Natural Environmental Research Council for its initial support of the work, and to the Leverhulme Trust for an Emeritus Fellowship to one of us (TRES)

\section{REFERENCES}

BAsset Y. \& ARthington A.H. 1992: The arthropod community of an Australian rainforest tree: abundance of component taxa, species richness and guild structure. Aust. J. Ecol. 17: 89-98.

Basset Y., Novotny V. \& Weiblen I.G. 1997: Ficus: a resource for arthropods in the tropics, with particular reference to New Guinea. In: Watts A., Stork N.E. \& Hunter M. (eds): Forests and Insects, Symp. R. Entomol. Soc. London. Chapman \& Hall, London, pp. 339-359.

Basset Y., Novotny V., Miller S.E. \& Kitching R.L. (eds) 2003: Arthropods of Tropical Forests. Cambridge University Press, Cambridge, 474 pp.

Buse A., Dury S.J., Woodburn R.J.W., Perrins C.M. \& Good J.E.G. 1999: Effects of elevated temperature on multi-species interactions. The case of Pedunculate Oak, Winter Moth and Tits. Funct. Ecol. 13 (supplement 1): 74-82.
Coley P.D., Bryant J.P. \& Chapin F.S. 1985: Resource availability and plant antiherbivore defense. Science 230: 895-899.

COLlyer E. 1951: A method for the estimation of insect populations on fruit trees. Rep. E. Malling Res. Stn 1949-50: $148-151$.

Colwell \& Coddington 1994: Estimating terrestrial biodiversity through extrapolation. Philosop. Trans. R. Soc., London B 345: 101-118.

FEeny P. 1970: Seasonal changes in oak leaf tannins and nutrients as a cause of spring feeding by winter moth caterpillars. Ecology 51: 565-581.

Hunter M.D. \& West C. 1990: Variation in the effects of spring defoliation on the late season phytophagous insects of Quercus robur. In Watt A.D., Leather S.R., Hunter M.D. \& Kidd N.A.C. (eds): Population Dynamics of Forest Insects. Intercept, Andover, pp. 123-135.

KenNEDy C.E.J. 1986: Attachment may be a basis for specialisation in oak aphids. Ecol. Entomol. 11: 291-300.

Kennedy C.E.J. \& Southwood T.R.E. 1984: The number of species of insect associated with British trees. A reanalysis. $J$. Anim. Ecol. 53: 455-478.

Kitching R.L., Bergelson J.M., Lowman M.D., McIntyre \& CARruthers G. 1993: The biodiversity of arthropods from Australian rainforest canopies: General introduction, methods, sites and ordinal results. Aust. J. Ecol. 18: 181-191.

Kitching R.L., Basset Y., Ozanne C. \& Winchester N. 2002: Canopy Knockdown Techniques for Sampling Canopy arthropod Fauna. In: Mitchell A.W., Secoy K. \& Jackson T. (eds): Global Canopy Handbook. Global Canopy Programme, Oxford, pp. 134-139.

Linsenmair K.E., Davis A.J., Fiala B. \& Speight M.R. (eds) 2001: Tropical Forest Canopies: Ecology and Management (Proceedings of ESF Conference, Oxford University, 12-16 December 1998). Kluwer Academic Publishers, Dordrecht, $370 \mathrm{pp}$.

MAJER J.D. \& RECHER H.F. 1988: Invertebrate communities on Western Australian eucapypts: a comparison of branch clipping and chemical knockdown procedures. Aust. J. Ecol. 13: 269-278.

MARTIN J.L. 1966: The insect ecology of red pine plantations in central Ontario. IV. The crown fauna. Can. Entomol. 98: $10-27$.

Moran V.C. \& Southwood T.R.E. 1982: The Guild composition of arthropod communities on trees. J. Anim. Ecol. 51: 289-306.

Novotny V, Basset Y., Miller S.E., Weiblen G.D., Bremer B, CizeK L. \& Droz D.P. 2002: Low host specificity of herbivorous insects in a tropical forest. Nature 416: 841-844.

Ozanne C.M.P., Speight, M.R., Hambler C. \& Evans H.F. 2000: Isolated trees and forest patches: patterns in canopy arthropod abundance and diversity in Pinus sylvestris (Scots Pine). Forest Ecol. Manag. 137: 53-63.

PERrins C.M. 1991: Tits and their caterpillar food supply. Ibis 138: $49-54$.

Recher H.F., Majer J.D. \& Ganesh S. 1996: Seasonality of canopy invertebrate communities in eucalypt forests of eastern and western Australia. Aust. J. Ecol. 21: 64-80.

Rogers L.E., Hinds W.T. \& Buschbom R.L. 1976: A general weight vs. length relationship for insects. Ann. Entomol. Soc. Am. 69: 387-389.

Southwood T.R.E. \& Kennedy C.E.J. 1983: Trees as islands. Oikos 41: 359-371.

Southwood T.R.E., Brown V.K. \& Reader P.M. 1986: Leaf palatability, life expectancy and herbivore damage. Oecologia 70: $544-548$. 
Southwood T.R.E., Moran V.C. \& Kennedy C.E.J. 1982a: The richness, abundance and biomass of the arthropod communities on trees. J. Anim. Ecol. 51: 635-649.

Southwood T.R.E., Moran V.C. \& Kennedy C.E.J. 1982b:The assessment of arboreal insect fauna: comparisons of knockdown sampling and faunal lists. Ecol. Entomol. 7: 331-340.

Southwood T.R.E. \& Henderson P.A. 2000: Ecological Methods (3rd Edition). Blackwell Science, Oxford. 575 pp.

Stork N.E. \& BRENDELL 1990: Variation in the insect fauna of Sulawesi trees with season, altitude and forest type. In: Knight W.J. \& Holloway J.D. (eds): Insects and Rain Forests of South East Asia (Wallacea), Chapter 18. Royal Entomological Society of London, London, pp. 173-190.

SToRK N.E. \& HAmmond P.M. 1997: Sampling arthropods from tree-crowns by fogging with knockdown insecticides: lessons from studies of oak tree beetle assemblages in Richmond Park (UK). In: Stork N.E., Adis J. \& Didham R.K. (eds): Canopy Arthropods. Chapman \& Hall, London, pp. 3-26.
Stork N.E., Adis J. \& Didham R.K. (eds) 1997: Canopy Arthropods. Chapman \& Hall, London, $567 \mathrm{pp}$.

WeLCH R.C. 1981: Insects on exotic broadleaved trees of the Fagaceae, namely Quercus borealis and species of Nothofagus. In: Last F.T. \& Gardiner A.S. (eds): Forest and Woodland Ecology, ITE Symposium 8: 110-115.

WEST C. 1983: Factors underlying the late seasonal appearance of the Lepidopterous leaf-mining guild on oak. Ecol. Entomol. 10 111-120.

WiNT G.R.W. 1983: The effect of foliar nutrients upon growth of a lepidopteran larva. In: Lee J.A., McNeill S. \& Rorison I.H. (eds) Nitrogen as an Ecological Factor. Symp. Brit. Ecol. Soc. 22: 301-320.

ApPendix 1: Data used for Figure 1.

\begin{tabular}{|c|c|c|c|c|c|c|c|c|c|c|c|c|c|}
\hline & & CERRIS & & & ILEX & & & PETRAEA & & & $R O B U R$ & & \\
\hline GUILD & Month & $\begin{array}{l}\text { Mean } \\
\text { Indiv/Sample }\end{array}$ & SD & $\mathrm{N}$ & $\begin{array}{l}\text { Mean } \\
\text { Indiv/Sample }\end{array}$ & SD & $\mathrm{N}$ & $\begin{array}{l}\text { Mean } \\
\text { Indiv/Sample }\end{array}$ & SD & $\mathrm{N}$ & $\begin{array}{l}\text { Mean } \\
\text { Indiv/Sample }\end{array}$ & SD & $\mathrm{N}$ \\
\hline Chewers & 4 & 1.5 & 2.1 & 2 & 1.0 & . & 1 & 4.7 & 2.1 & 3 & 25.2 & 14.3 & 5 \\
\hline Chewers & 5 & 11.0 & 5.2 & 9 & 2.6 & 1.5 & 5 & 206.3 & 220.4 & 8 & 167.0 & 91.4 & 18 \\
\hline Chewers & 6 & 35.3 & 17.8 & 9 & 12.4 & 12.7 & 5 & 40.4 & 21.6 & 8 & 46.6 & 24.0 & 18 \\
\hline Chewers & 7 & 7.5 & 3.5 & 2 & 6.0 & . & 1 & 18.1 & 7.7 & 7 & 22.4 & 11.5 & 16 \\
\hline Chewers & 8 & 2.5 & 1.3 & 8 & 3.0 & 3.4 & 4 & 10.7 & 7.8 & 10 & 15.8 & 7.5 & 17 \\
\hline Chewers & 9 & 2.3 & 1.5 & 3 & 3.0 & 1.4 & 5 & 14.0 & 5.0 & 3 & 12.0 & 2.8 & 5 \\
\hline \multirow[t]{2}{*}{ Chewers } & 10 & 2.0 & 1.4 & 2 & 1.0 & . & 1 & 8.0 & 7.8 & 3 & 4.4 & 2.0 & 5 \\
\hline & Mean & 13.3 & 16.4 & 35 & 5.0 & 7.1 & 22 & 54.5 & 118.7 & 42 & 55.7 & 73.8 & 84 \\
\hline Suckers & 4 & 0.5 & 0.7 & 2 & 0.0 & . & 1 & 0.0 & 0.0 & 3 & 0.0 & 0.0 & 5 \\
\hline Suckers & 5 & 5.3 & 4.3 & 9 & 18.4 & 27.8 & 5 & 57.6 & 40.0 & 8 & 47.2 & 34.8 & 18 \\
\hline Suckers & 6 & 33.3 & 31.1 & 9 & 121.4 & 203.1 & 5 & 80.6 & 55.8 & 8 & 58.7 & 50.7 & 18 \\
\hline Suckers & 7 & 7.5 & 3.5 & 2 & 63.0 & . & 1 & 69.4 & 44.7 & 7 & 51.9 & 28.6 & 16 \\
\hline Suckers & 8 & 53.8 & 100.0 & 8 & 20.0 & 19.6 & 4 & 23.5 & 12.3 & 10 & 28.5 & 41.7 & 17 \\
\hline Suckers & 9 & 13.3 & 11.2 & 3 & 0.0 & 0.0 & 5 & 27.3 & 13.1 & 3 & 13.2 & 5.1 & 5 \\
\hline \multirow[t]{2}{*}{ Suckers } & 10 & 0.5 & 0.7 & 2 & 0.0 & . & 1 & 2.0 & 2.0 & 3 & 2.0 & 2.4 & 5 \\
\hline & Mean & 23.9 & 52.1 & 35 & 38.3 & 101.9 & 22 & 45.6 & 44.0 & 42 & 39.2 & 40.3 & 84 \\
\hline GUILD & Month & $\begin{array}{l}\% \text { leaves } \\
\text { attacked }\end{array}$ & $\mathrm{SD}$ & $\mathrm{N}$ & $\begin{array}{l}\% \text { leaves } \\
\text { attacked }\end{array}$ & SD & $\mathrm{N}$ & $\begin{array}{l}\% \text { leaves } \\
\text { attacked }\end{array}$ & SD & $\mathrm{N}$ & $\begin{array}{l}\% \text { leaves } \\
\text { attacked }\end{array}$ & SD & $\mathrm{N}$ \\
\hline Mines & 4 & 0.00 & 0.00 & 2 & 0.00 & $\cdot$ & 1 & 0.00 & 0.00 & 3 & 0.00 & 0.00 & 5 \\
\hline Mines & 5 & 0.00 & 0.00 & 9 & 3.27 & 10.85 & 11 & 0.00 & 0.00 & 8 & 0.17 & 0.38 & 18 \\
\hline Mines & 6 & 2.33 & 1.32 & 9 & 0.00 & 0.00 & 8 & 11.13 & 4.02 & 8 & 8.00 & 6.38 & 18 \\
\hline Mines & 7 & 1.50 & 2.12 & 2 & 0.10 & 0.32 & 10 & 21.60 & 6.22 & 10 & 10.57 & 11.09 & 7 \\
\hline Mines & 8 & 1.00 & 1.00 & 5 & 0.29 & 0.76 & 7 & 22.18 & 11.50 & 11 & 27.07 & 14.01 & 14 \\
\hline Mines & 9 & 3.00 & 4.24 & 2 & 4.80 & 4.76 & 5 & 22.00 & 4.24 & 2 & 16.25 & 7.54 & 4 \\
\hline \multirow[t]{2}{*}{ Mines } & 10 & 8.50 & 4.95 & 2 & 0.00 & . & 1 & 57.00 & 17.35 & 3 & 60.80 & 14.45 & 5 \\
\hline & Mean & 1.68 & 2.57 & 31 & 1.47 & 5.80 & 43 & 16.98 & 15.97 & 45 & 13.65 & 18.32 & 71 \\
\hline Galls & 4 & 0.00 & 0.00 & 2 & 0.00 & . & 1 & 0.00 & 0.00 & 3 & 0.00 & 0.00 & 5 \\
\hline Galls & 5 & 0.00 & 0.00 & 9 & 0.00 & 0.00 & 11 & 2.25 & 3.28 & 8 & 3.83 & 4.93 & 18 \\
\hline Galls & 6 & 0.3 & 0.50 & 9 & 0.00 & 0.00 & 8 & 3.88 & 3.36 & 8 & 2.06 & 1.80 & 18 \\
\hline Galls & 7 & 3.00 & 1.41 & 2 & 1.10 & 2.51 & 10 & 1.30 & 2.11 & 10 & 0.86 & 1.86 & 7 \\
\hline Galls & 8 & 0.60 & 1.34 & 5 & 0.00 & 0.00 & 7 & 17.91 & 18.32 & 11 & 5.79 & 6.17 & 14 \\
\hline Galls & 9 & 0.00 & 0.00 & 2 & 0.20 & 0.45 & 5 & 16.50 & 16.26 & 2 & 13.00 & 11.22 & 4 \\
\hline \multirow[t]{2}{*}{ Galls } & 10 & 0.00 & 0.00 & 2 & 0.00 & . & 1 & 0.33 & 0.58 & 3 & 1.80 & 1.92 & 5 \\
\hline & Mean & 0.39 & 0.95 & 31 & 0.28 & 1.26 & 43 & 6.51 & 11.83 & 45 & 3.58 & 5.31 & 71 \\
\hline
\end{tabular}


Appendix 2: "Oak Codes"

The oak codes were used to provide a quantitative indication of the extent of specialisation by the phytophage on oaks (Quercus) and/or the botanical distance of their recognised host plants from oaks. They were based on the descriptions of the habitat in standard works of identification, e.g. the Handbooks for the Identification of British Insects series.

12 Quercus only - "oaks".

11 Quercus + Fagaceae - e.g. "Quercus, Fagus, Castanea".

10 Quercus + Fagales - e.g. "Quercus, Fagus, Carpinus, Corylus" - Quercus mentioned first.

9 Quercus + others - oak mentioned first + others including non-Fagales.
8 Others + Quercus - various trees, Quercus specified but not first.

7 Other Facaceae, but oak not mentioned, e.g. Fagus and Castanea.

6 Facaceae + others, but Quercus not mentioned.

5 Fagales, but no Fagaceae mentioned, e.g. Betula, Corylus and Alnus.

4 Fagales, no Fagaceae mentioned, but non-Fagales included, e.g. Betula, Salix and Rubus.

3 No Fagales, but other dicotyledon trees and shrubs, e.g. Acer, Ulmus, Crateagus or general, e.g. "Trees".

2 No trees or shrubs, but dicotyledon herbs.

1 No dicotyledon plants mentioned, e.g. "grasses".

Received July 15, 2003; revised November 28, 2003. accepted December 2, 2003 